\title{
Effects of low temperature drying processing on longan fruit
}

\author{
Thadchapong Pongsuttiyakorn ${ }^{1, *}$, Pachareeporn trusphimai ${ }^{1}$, Pitikhate Sooraksa ${ }^{2}$, and Pimpen Pornchaloempong ${ }^{1}$ \\ ${ }^{1}$ Food Engineering Department, Faculty of Engineering, King Mongkut's Institute of Technology Ladkrabang, Bangkok, Thailand \\ ${ }^{2}$ Computer Engineering Department, Faculty of Engineering, King Mongkut's Institute of Technology Ladkrabang, Bangkok, Thailand
}

\begin{abstract}
In this study, the single-stage drying in tray dryer at air temperatures of $40,50,60,70$ and $80^{\circ} \mathrm{C}$ is modelled and investigated. The longan fruits, E-dor variety, are peeled and seeded before testing. The drying rate is significantly influenced by the drying techniques and temperatures. Drying rats are initialized adjustment constant rate periods at 6070 and $80^{\circ} \mathrm{C}$. The rate of moisture removal is rapidly changed drastically during the falling rate period. The Midilli model with high $\mathrm{R}^{2}$ and low $\chi^{2}$ and RMSE is the most suitable model for predictability of longan drying. Variation rates of quality of the water activity, the shrinkage, and the browning index are also reported.
\end{abstract}

\section{Introduction}

Longan (Dimocarpus Longan Lour.) is a tropical fruit mainly produced in Thaïland. The fruit has a brown to light reddish-brown peel. The pulp is juicy and sweet, with a white, translucent flesh. Transformed longans are exported as fresh $(76 \%)$, dried $(22 \%)$, canned $(2 \%)$ and frozen fruits $(<0.5 \%)$ (Ministry of Agriculture and Cooperatives). That are mainly exported to China, Vietnam, Hong Kong, Indonesia and others. But longan is a seasonal fruit crop, it involves variations in production values. This sometimes leads to, over supply problems and low prices during high production periods. From the export value, dried longan is interested product. There are a lot of longan drying methods, such as solar drying of peeled longan [1].

Actually, rapid drying at high temperatures may reduce the cost of processing. However, the quality of the product may be reduced. Drying of high quality Longan have been proposed by various ways which are: a two-stage superheated steam drying followed by hot air drying process [2]. There are also forced convection and hot air recirculation in longan drying [3], multi-stage dying processes using heat pump for longan drying at temperature of $55^{\circ} \mathrm{C}$, combined far-infrared-heat pump drying at temperature of $65^{\circ} \mathrm{C}$, and combined far-infrared -hot air drying with $80 \%$ recycled air [4].

The qualities of dried longan such as moisture content, water activity and color effect on prices of product. The color characteristics of longan flesh are increased at the beginning and decreases as drying time and drying air temperature increase during air drying [5].

Prediction of longan drying by theoretical methods assumes that material moisture is conveyed by geometric diffusion. The answer to this model is effective diffusion coefficient. However, for empirical equations it is easy to use and has been widely used since it is based on experimental data. [6]
Development of a low temperature drying process for whole longan fruit is of great interest, in maintaining quality. The purpose of this research is to study the effects of low temperature drying on the drying kinetics.

\section{Material and method}

\subsection{Material}

Longans of E-dor variety (Dimocarpus Longan Lour.) were purchased from Talaadthai market in Pathum Thani province. The samples were peeled and seeded before experiment. The longan fleshes were approximate inner and outer diameters of 15 and $25 \mathrm{~mm}$, respectively. The longans had average total soluble solid of 17.018.4.\%brix and initial moisture content of 77.7-80.4 $\%$ (w.b.)

\subsection{Drying of longans}

\subsubsection{Drying experiment}

The drying experiments were performed in a laboratory scale hot air dryer. The experiments were conducted at drying temperatures of 40,50, 60, 70 and $80^{\circ} \mathrm{C}$ with a constant air velocity of $1.08 \mathrm{~m} / \mathrm{s}$ and recorded temperature and relative humidity every 1 minute and sampling of measurement every 1 hour.

\subsubsection{Drying rate}

In each drying experiment, 180 longan fruits were placed on three trays (average weight of $300 \mathrm{~g}$ ). During drying, at temperatures of 40 and $50^{\circ} \mathrm{C}$, the samples were weighed every half hour, and at temperatures of 60,70

* Corresponding author: author@e-mail.org 
and $80^{\circ} \mathrm{C}$, the samples were weighed every 10 minutes until the weight of the sample was constant.

Rate of drying curves. Data acquired usually obtained from the total weight is $W_{t}$ and the weight of the dry solid is $W_{s}$ in $\mathrm{kg}$ then:

$$
M_{t}=\left(W_{t}-W_{s}\right) / W_{s}
$$

For the given constant drying conditions, the equilibrium moisture content is $M_{e}\left(\mathrm{~kg}_{\text {equilibrium moisture }} / \mathrm{kg}_{\text {dry solid }}\right)$, and the free moisture content is $M\left(\mathrm{~kg}_{\text {free water }} / \mathrm{kg}_{\text {dry solid }}\right)$, the water can be removed by mechanical methods and can be calculated for moisture content at different times over the drying period $\left(\mathrm{kg}_{\text {water }} / \mathrm{kg}_{\text {dry solid }}\right)$ is $M_{t}$

$$
M=M_{t}-M_{e}
$$

The drying rate $(R)$ is calculated for each drying time increment using:

$$
R=\left(W_{s} / A\right) \times(d x / d t)
$$

where $A$ is the exposed surface area for drying $\left(\mathrm{m}^{2}\right), d x / d t$ is free moisture content of bulb at different times.

The moisture ratio $(M R)$ : In thin layer drying, the moisture ratio was calculated using equation:

$$
M R=\left(M_{t}-M_{e}\right) /\left(M_{i}-M_{e}\right)
$$

Where $M_{t}$ is the moisture content at different times $\left(\mathrm{kg}_{\text {water }} / \mathrm{kg}_{\text {dry }}\right.$ solid $), M_{i}$ is the initial moisture content $\left(\mathrm{kg}_{\text {water }} / \mathrm{kg}_{\text {dry solid }}\right)$, and $M_{e}$ is the equilibrium moisture content of the samples $\left(\mathrm{kg}_{\text {water }} / \mathrm{kg}_{\text {dry solid }}\right)$ [7]

\subsubsection{Mathematical modelling of drying curves}

In the present study, the obtained drying data (time versus MR) are empirical modeled by 5 different models and equations of them are presented in Table 1.

Table 1. Empirical models used in the present study to fit data obtained from drying at different conditions.

\begin{tabular}{|c|l|l|c|}
\hline No. & \multicolumn{1}{|c|}{ Model } & \multicolumn{1}{|c|}{ Equation } & Ref \\
\hline 1 & Lewis & $M R=\exp (-k t)$ & {$[8]$} \\
\hline 2 & Page & $M R=\exp \left(-k t^{n}\right)$ & {$[9]$} \\
\hline 3 & $\begin{array}{l}\text { Henderson and } \\
\text { Pabis }\end{array}$ & $M R=a \times \exp (-k t)$ & {$[10]$} \\
\hline 4 & Wang and Singh & $M R=1+a t+b t 2$ & {$[11]$} \\
\hline 5 & Midilli & $M R=a \times \exp \left(-k t^{n}\right)+b t$ & {$[12]$} \\
\hline
\end{tabular}

Drying data of the samples were analyzed using SPSS 2.0 software (International Business Machines Corp., United States). Nonlinear regression analysis was calculated corresponding parameters of the models mentioned in Table 1. Validation of the statistical models was determined using $\mathrm{R}^{2}, \chi^{2}$ and $\mathrm{RMSE}$ values calculated using the following equations:

$$
\begin{gathered}
R^{2}=1-\sum\left(y_{\text {exp }}-y_{\text {pred }}\right)^{2} / \sum\left(y_{\text {exp }}-y_{\text {ave }}\right)^{2} \\
\chi^{2}=(1 / N) \times \sum\left(y_{\text {exp }}-y_{\text {pred }}\right)^{2} \\
R M S E=\left[(1 / N) \times \sum\left(y_{\text {exp }}-y_{\text {pred }}\right)^{2}\right]^{1 / 2}
\end{gathered}
$$

where $y_{\text {exp }}$ and $y_{\text {pred }}$ are the experimental and predicted, and $N$ are the number of observations [13].

\subsection{Moisture content}

Take a sample of longan fruit before and after drying about $3-5 \mathrm{~g}$. and cut into small pieces. To measure the moisture content of the product before and after drying, longans dried measuring in the moisture analyzer with MA37-1 (Sartorius, German) at $90^{\circ} \mathrm{C}$.

\subsection{Water activity}

Take a sample of longan fruit after drying to about 3 g. and cut into small pieces. To measure the water activity of the product after drying, the sample was measured by using Aqua lab LITE (Decagon, USA).

\subsection{Shrinkage}

Longans fruit 10 units, measured the volume of the product before and during drying with Hexane using the density kit analytical balance ydk03 (Sartorius, German). And then calculated the Shrinkage of the product using the following equations:

$$
\% \text { Shrinkage }=\left[\left(V_{0}-V\right) / V_{0}\right] \times 100
$$

where $V_{0}$ and $V$ are the volume initiate and volume, respectively.

\subsection{Browning index}

Samples were analysed at different times of longan drying and for each temperature, to extract brown pigments. Take the same amount of solids $(1.0 \mathrm{~g})$. Samples were ground and mix with $25 \mathrm{ml}$ of $20 \%$ acetic acid. After $24 \mathrm{~h}$, they were filtered through a funnel with Whatman No. 2 filter paper. After that, the absorbance was measured in $10 \mathrm{~mm}$ cells against $20 \%$ acetic acid at 420 $\mathrm{nm}$. Two measurements for each situation were carried out by using. THERMOSCIENTIFIC Genesys 10S UVvis Absorbance [14-15].

\section{Results and discussion}

The resulting longan drying at 40, 50, 60, 70 and $80^{\circ} \mathrm{C}$. Data was analyzed to determine the drying rate and the quality of the change over time during drying.

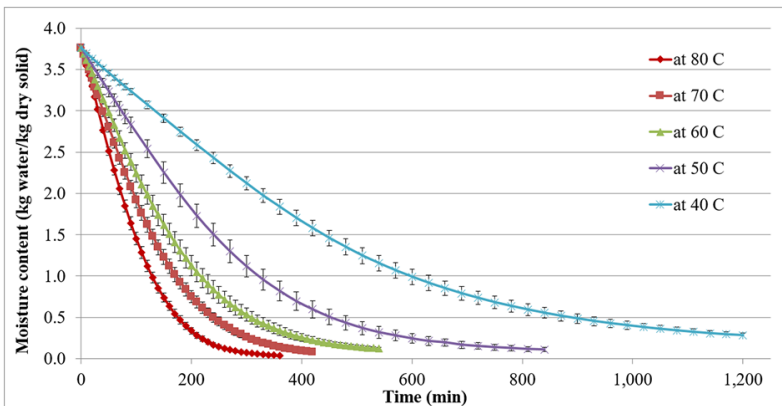

Fig. 1. Drying curves of the longan. 
Drying curves and moisture content versus time were given in Figure 1. Our results were agreed with the other studies using different materials for drying [2, 6-7]. The drying time was shorter when the temperature rises. Drying time the longest in the shortest drying time at $80^{\circ}$ $\mathrm{C}$, it took around $360 \mathrm{~min}$.

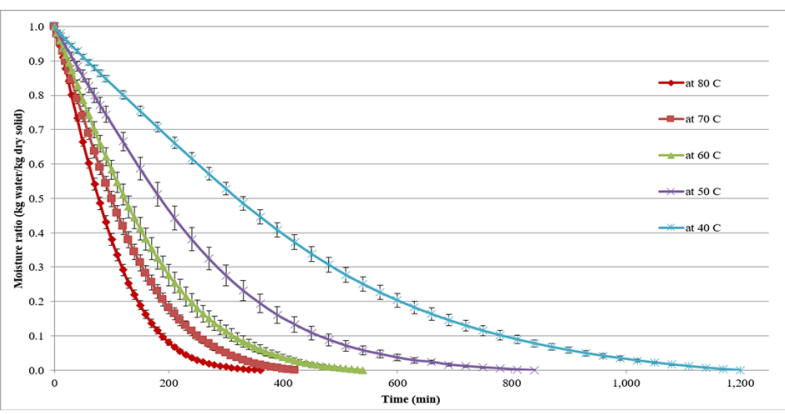

Fig. 2. Moisture ratio versus time for drying of the longan.

The moisture content for all drying at different temperatures was reduced. As shown in the Figure 2, the slope of the curve represents the change in drying rate during the drying period.

Figure 3 shows the drying rate of dried longans at various temperatures drying at 60,70 and $80^{\circ} \mathrm{C}$ with an initial adjustment period. Due to the increase in surface temperature, the higher the temperature, the more steep, none for drying at 40 and $50^{\circ} \mathrm{C}$. During the constant rate period, at constant rates, the surface moisture removal rate of the sample is saturated with water for only a short time [7]. Overall, drying in the falling rate period followed by a constant rate period.

Drying time versus moisture ratio with different temperatures. The corresponding parameters of the

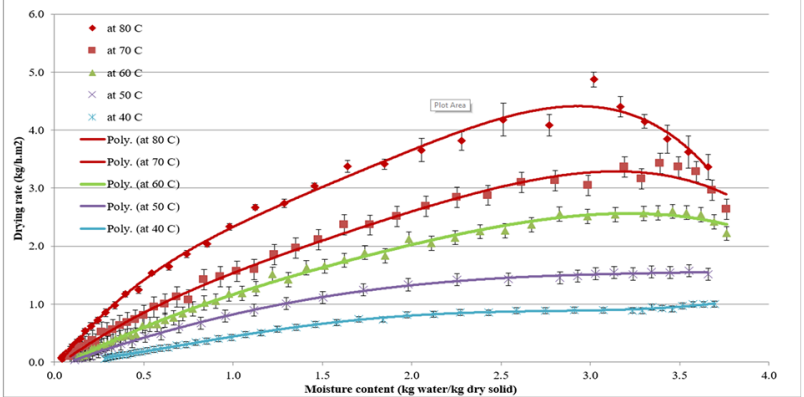

Fig. 3. Variation of the drying rate with the moisture content of longan.

empirical models and the $\mathrm{R}^{2}, \chi 2$ and RMSE values for the accuracy of the models are presented in Table 2.

The $\mathrm{R}^{2}$ values is between 0.984038 and 0.999915 , which is more than 0.95 , indicating that the predicted data is close to the experimental data. Therefore, all models can explain the relationship between time and relative humidity and the drying process [13]. The RMSE values represent the difference between the predicted value and the experimental value. Between 0.000008 and 0.072017 , the most suitable models for longan were Midilli and Wang and Singh, respectively. Obtaining the drying kinetics data is essential for optimizing the drying process, The $k$ coefficient represents the drying rate [16]. From tables $2, k$ increases as the drying temperature increases.

The water activity of the dried food product must be less than 0.6. However, the final drying product at $40 \mathrm{c}$ is more than 0.6 , is 0.7440 , which was not met the criterion. For drying at $50,60,70$ and $80^{\circ} \mathrm{C}$, the water activity was less than 0.6 , is $0.5447,0.5220,0.5040$ and 0.4110 , respectively as shown in Figure 4.

Table 2. Empirical model parameters and statistical parameters obtained from fitting of the drying models for longans.

\begin{tabular}{|c|c|c|c|c|c|c|c|}
\hline No. & & & 40 & 50 & 60 & 70 & 80 \\
\hline \multirow{4}{*}{1} & \multirow{4}{*}{$\begin{array}{l}\text { Lewis } \\
M R=\exp (-k t)\end{array}$} & $\mathrm{k}$ & 0.002488 & 0.004212 & 0.006408 & 0.007912 & 0.010318 \\
\hline & & $\mathrm{R}^{2}$ & 0.984960 & 0.988093 & 0.986819 & 0.985279 & 0.984038 \\
\hline & & $\chi^{2}$ & 0.000241 & 0.000158 & 0.000990 & 0.000583 & 0.000662 \\
\hline & & RMSE & 0.015313 & 0.012408 & 0.031191 & 0.023889 & 0.025409 \\
\hline \multirow{5}{*}{2} & \multirow{5}{*}{$\begin{array}{l}\text { Page } \\
M R=\exp \left(-k t^{n}\right)\end{array}$} & $\mathrm{k}$ & 0.000448 & 0.001056 & 0.001651 & 0.001990 & 0.002429 \\
\hline & & $\mathrm{n}$ & 1.279378 & 1.248919 & 1.259123 & 1.275542 & 1.305251 \\
\hline & & $\mathrm{R}^{2}$ & 0.998623 & 0.999410 & 0.999448 & 0.999356 & 0.999569 \\
\hline & & $\chi^{2}$ & 0.001895 & 0.000552 & 0.000709 & 0.000660 & 0.000432 \\
\hline & & RMSE & 0.042983 & 0.023151 & 0.026390 & 0.025414 & 0.020525 \\
\hline \multirow{5}{*}{3} & \multirow{5}{*}{$\begin{array}{l}\text { Henderson and Pabis } \\
M R=a \times \exp (-k t)\end{array}$} & $\mathrm{k}$ & 0.002640 & 0.004515 & 0.006830 & 0.008472 & 0.011145 \\
\hline & & a & 1.056636 & 1.061607 & 1.066873 & 1.070407 & 1.079348 \\
\hline & & $\mathrm{R}^{2}$ & 0.989326 & 0.992672 & 0.991622 & 0.990789 & 0.990457 \\
\hline & & $\chi^{2}$ & 0.005167 & 0.003018 & 0.005277 & 0.004532 & 0.004633 \\
\hline & & RMSE & 0.070979 & 0.054147 & 0.072017 & 0.066584 & 0.067212 \\
\hline \multirow{5}{*}{4} & \multirow{5}{*}{$\begin{array}{l}\text { Wang and Singh } \\
M R=1+a t+b t^{2}\end{array}$} & $\mathrm{a}$ & -0.001816 & -0.002994 & -0.004533 & -0.005652 & -0.007174 \\
\hline & & $\mathrm{b}$ & 0.000001 & 0.000002 & 0.000005 & 0.000008 & 0.000013 \\
\hline & & $\mathrm{R}^{2}$ & 0.999246 & 0.996710 & 0.996518 & 0.997761 & 0.995546 \\
\hline & & $\chi^{2}$ & 0.000002 & 0.000159 & 0.000202 & 0.000026 & 0.000059 \\
\hline & & RMSE & 0.001366 & 0.012442 & 0.014078 & 0.005009 & 0.007582 \\
\hline \multirow{7}{*}{5} & \multirow{7}{*}{$\begin{array}{l}\text { Midilli } \\
M R=a \times \exp \left(-k t^{n}\right)+b t\end{array}$} & $\mathrm{k}$ & 0.000437 & 0.000935 & 0.001679 & 0.002117 & 0.002327 \\
\hline & & $\mathrm{n}$ & 1.271245 & 1.263392 & 1.248481 & 1.254274 & 1.308277 \\
\hline & & $\mathrm{a}$ & 0.980728 & 0.984676 & 0.988718 & 0.990528 & 0.989360 \\
\hline & & $\mathrm{b}$ & -0.000025 & -0.000016 & -0.000030 & -0.000049 & -0.000029 \\
\hline & & $\mathrm{R}^{2}$ & 0.999807 & 0.999830 & 0.999913 & 0.999915 & 0.999844 \\
\hline & & $\chi^{2}$ & 0.000000 & 0.000001 & 0.000000 & 0.000000 & 0.000001 \\
\hline & & RMSE & 0.000636 & 0.000873 & 0.000015 & 0.000498 & 0.000776 \\
\hline
\end{tabular}




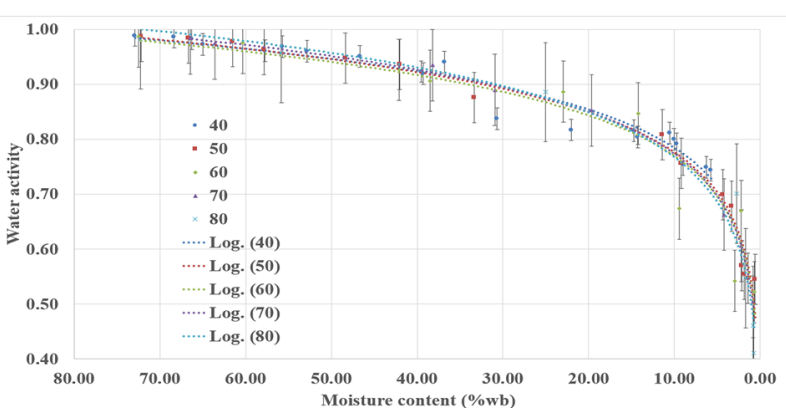

Fig. 4. Variation of the water activity with the moisture content of longans.

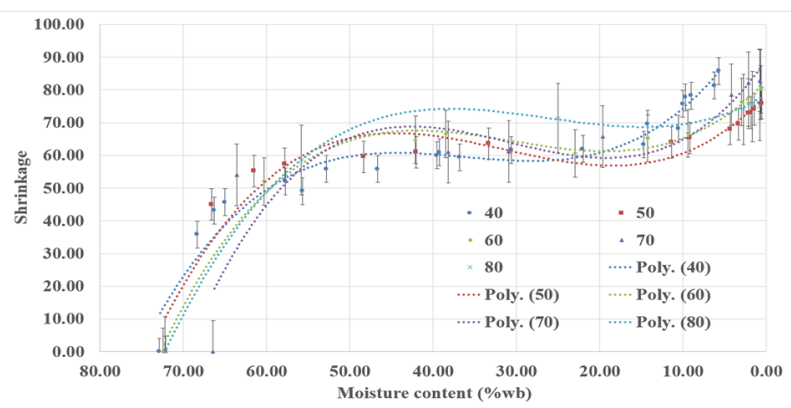

Fig. 5. Variation of the shrinkage with the moisture content of longan.

The rates of shrinkage of longan drying at the beginning of the experiment are shown in Figure 5. The shrinkage rate was high and decreased and the rate of contraction was even higher. The final shrinkage of longans for drying at temperatures of 40, 50, 60, 70 and $80{ }^{\circ} \mathrm{C}$ were 85.8014, 75.901, 80.165, 82.9295 and 81.6251 , respectively.

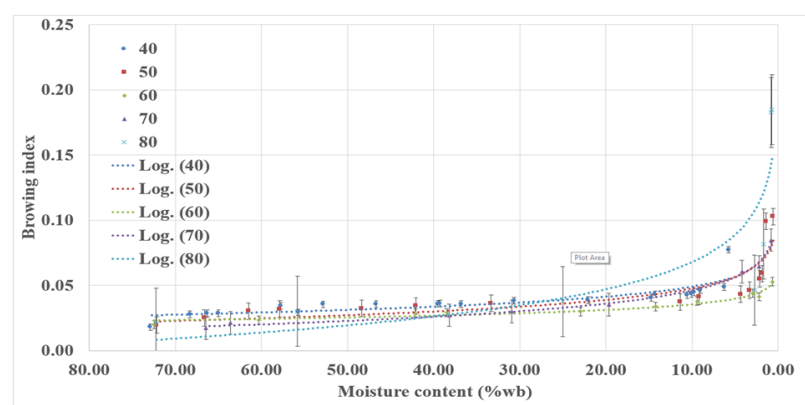

Fig. 6. Variation of the Browning index with the moisture content of longan.

Figure 6 shows the browning rate during drying increases due to increasing in solids content. The rate of browning in first period was slightly changed due to the high moisture content. When moisture content dropped below $20 \% \mathrm{wb}$, the brown index became more variation by the temperature affecting the rate of change. The Browning index of longans for drying processes at 40, 50, 60,70 and $80^{\circ} \mathrm{C}$ were $0.077,0.102,0.052,0.084$ and 0.184 , respectively

\section{Conclusion}

The study of product temperature and moisture content on the drying time reveals practical information for the final decision of drying processing with low temperature. Drying of longans showed initial adjustment periods at 6070 and $80^{\circ} \mathrm{C}$. At the constant rate period, the moisture removal was rapidly increased and was drastically removed at the falling rate period. The midilli model with the higher $\mathrm{R}^{2}$ and lower $\chi^{2}$ and RMSE values has the most suitable model for predictability of longan drying. The water activity of the dried longans was lower than 0.6 as desired, except for drying at $40^{\circ} \mathrm{C}$. The shrinkage rate was high and decreased. The rate of browning index has increased, when the moisture content drops below $20 \%$ wb. For future research, the effect of moisture ratio of this drying on the quality will be observed.

\section{References}

1. S. Janjai, N. Lamler, P. Intawee, B. Mahayothee, B.K. Bala, M. Nagle, J. Müller. Elsevier Ltd., Solar Energy, 83, 1550-1565 (2009)

2. T. Somjai, S. Achariyaviriya, A. Achariyaviriya, K. Namsanguan. Journal of Food Engineering, 95, 313321 (2009)

3. N. Tippayawong*, C. Tantakitti, S. Thavornun, V. Peerawanitkul. Biosystems engineering, 104, 199204 (2009)

4. A. Nathakaranakule, P. Jaiboon, S. Soponronnarit. Journal of Food Engineering, 100, 662-668 (2010)

5. S. Chunthaworn, S. Achariyaviriya, A. Achariyaviriya, K. Namsanguan. Procedia Engineering, 32, 104 - 111 (2012)

6. S. Surbkar, R. Assawarachan. Thai Society of Agricultural Engineering Journal, 17, 1 59-66 (2011)

7. R.Ş. Çakmak, O. Tekeoğlu, H. Bozkır, A.R. Ergün, T. Baysal. Food Science and Technology, 69, 197202 (2016)

8. D.M.Bruce. Journal of Agricultural Engineering Research, 32, 337-347 (1985)

9. P. S. Madamba, R. H. Driscoll, K. A. Buckle. Journal of Food Engineering, 29, 75-97 (1996)

10. S. M. Henderson, S. Pabis. Journal of Agricultural Engineering Research, 6, 169-174 (1961)

11. G.Y. Wang, R. P. Singh. American Society of Agricultural Engineers, 73, 3001 (1978)

12. A. Midilli, H. Kucuk. Energy Conversion and Management, 44, 1111-1122 (2003)

13. M. Başlar, M. Kılıçlı, O.S. Toker, O. Sağdıç, M. Arici. Innovative Food Science and Emerging Technologies, 26, 182-190 (2014)

14. P. Udomkun, M. Nagle, B. Mahayothee, D. Nohr, A. Koza, J. Müller. Food Science and Technology, 60, 914-922 (2015)

15. H. JinPark, Y. Lee, J. BangEun. Biocatalysis and Agricultural Biotechnology, 5, 193-198 (2016)

16. M.J. Perea-Flores, V. Garibay-Febles, J.J. ChanonaPérez, G. Calderón-Domínguez, J.V. MéndezMéndez, E. Palacios-González, et al. Industrial Crops and Products, 38, 64-71 (2012)

\footnotetext{
Corresponding author: author@e-mail.org
} 